\title{
Instabilitási indexek vizsgálata radarmérések és modelleredmények alapján
}

\author{
Hegedüs Adrienn ${ }^{1}$ - Seres András Tamás ${ }^{2}$ - Breuer Hajnalka ${ }^{3}$ - Fodor Zoltán ${ }^{4}$ \\ 'egyetemi hallgató, ELTE TTK,E-mail: adri04@caesar.elte.hu \\ 2meteorológus fötiszt, Magyar Honvédség Geoinformációs Szolgálat, E-mail: seres.andrastamas@upcmail.hu \\ ${ }^{3}$ tanársegéd, Eötvös Loránd Tudományegyetem, Meteorológiai Tanszék,E-mail: bhajni@nimbus.elte.hu \\ ${ }^{4}$ osztályvezetö, Országos Meteorológiai Szolgálat.E-mail: fodor.z@met.hu
}

\section{Kulcsszavak}

\section{zivatar}

radarmérés

GFS modell

instabilitási index

Magyarország

\begin{abstract}
Absztrakt
A konvektiv idöjárási jelenségek térben és időben kis skálán zajlanak, ezért az elörejelzésük nem könnyü feladat. A légköri konvekció erösségének számszerüsitésére ún. instabilitási vagy labilitási indexeket használtunk, melyek alkalmazása lehetövé teszi a konvektiv környezet egyetlen számértékkel való jellemzését. A heves konvekciót vizsgáló kutatásunk alapvetó célja, hogy kideritsük, a gyakorlatban mely labilitási indexek segithetik leginkább a zivatartevékenységgel járó jelenségek lehetö legpontosabb elörejelzéseit. Ezt hazai radarméréseknek, illetve az amerikai GFS modell eredményeinek objektív feldolgozásával és összehasonlitásával végezzük. A keletkezö zivatarok radarképeken megjelenö, szabálytalan alakú alakzatait számunkra ismert tulajdonságú ellipszisekkel modellezzük. A kutatás során csak heves zivatarellipsziseket vizsgáltunk, mely objektumok legalább $20 \mathrm{~km}^{2}$-nyi területen minimum 45 dBZ-s reflektivitással rendelkeznek. A detektált zivatarellipszisek száma, illetve a labilitási energia függvényében hattagú osztályozási rendszert alkalmazunk, eredményeink megjelenitéséhez pedig dobozdiagramokat használunk. A vizsgált idöszak a 2011-2013 közti zivataros félévek (április-szeptember), a vizsgált terület pedig Magyarország. A vizsgálat során összesen 52 instabilitási, nedvességi és szélnyírási paramétert elemzünk. Közülük a Lifted és a Best Lifted Index, a Thompson Index, a K-Index, a leglabilisabb kevertrétegü konvektiv hasznositható potenciális energia, valamint a kihullható vízmennyiség és a specifikus nedvesség esetében elmondható, hogy a heves konvekció megjelenése, mértéke relativ szük tartományokhoz köthetö. Ebböl következően segitségünkre lehetnek a kérdés eldöntésében, kell-e számitani egy adott területen kialakuló vagy épp odaérkezö intenziv konvektiv jelenségre.
\end{abstract}

különböző feljegyzések. Váradi 1898-ban megjelent cikke alapján a zivatarképződés és a napsugárzás beesési szöge kapcsolatba hozható egymással: a földfelszín erőteljesebb felmelegedése esetén (azaz a beesési szög merölegeshez közeli) intenzívebb zivatartevékenység várható. Szalay-Ujfalussy (1917) szerint a zivatarok létrejöttéhez minden esetben ugrásszerü nyomásváltozásra van szükség.

A heves konvektív jelenségek idő- és térbeli előfordulásáról már számos tanulmány jelent meg. Riegl (1902) alapján a májustól októberig tartó időszakot nyári, zivataros félévnek nevezzük. Hegyfoky (1912) kutatásai alapján a zivatarok napi megjelenési maximuma körülbelül délután 2-3 óra körülre tehetö, területi eloszlásban pedig a tengerpartokat, a hegyvidékeket és a síkvidéke-
A zivatarok jellemzőivel kapcsolatos hazai tapasztalatokról már az 1900-as évek előtt is jelentek meg 
ket tekintve a kialakulási maximum folyamatosan későbbre tolódva, délután 1 és 4 óra között változik. Szudár 1992-es eredményeiböl kiderül, hogy a hazánk területére érkező zivatarok jelentős része Ausztria felöl, közülük a prefrontálisak délnyugati, a frontálisak pedig északnyugati irányból érkeznek.

Seres (2006), Horváth, Ács és Seres (2008), illetve Énekes (2010) és Kohlmann (2013) már radarméréseken alapuló zivatarstatisztikai, zivatarklimatológiai kutatásokat végzett. Az első két munkában többek között megállapították, hogy a legtöbb heves konvektív objektum hazánk délnyugati, illetve északi, északkeleti tájain fordult elö, továbbá a tér- és időbeli sajátosságok mellett a jelenségek szinoptikai háttereit is vizsgálták. Énekes munkájára a következő fejezetben térünk ki, míg Kohlmann megalkotott egy, mind a gyakorlatban, mind pedig a további kutatásokban jól használható esetleválogató programot, amely segítségével vizsgálhatók az egyes konvektív paraméterek szinoptikus klimatológiai tulajdonságai.

\section{Célkitúzés}

Kutatásunk közvetlen előzményének Énekes (2010) munkája tekinthető, amely a 2009-es év megfelelő időszakára vizsgálta meg a Magyarország területén detektálható, minimum $40 \mathrm{dBZ}$-s radarjel-erősséggel (más néven reflektivitással) rendelkező objektumokat. Jelenlegi elemzésünkben a vizsgált időszak hosszán túl a reflektivitás küszöbértékét is megnöveljük. A magasabb küszöbérték segítségével célunk a heves konvektív cellák azonosítása, illetve azok környezetének labilitási indexekkel és egyéb nedvességi, szélnyírási mennyiségekkel történő minél pontosabb jellemzése. Azoknál a változóknál, amelyeknél a stabilis $(O(S))$ és a labilis $(O(L))$ légköri helyzetek jól elkülöníthetők egymástól, szeretnénk küszöbértékeket kijelölni a heves konvekció kialakulásának lehetőségét illetően. Fontosnak tartjuk továbbá a változók előfordult abszolút minimum-, illetve maximumértékeinek vizsgálatát is a megfelelö időszakra, amelyek legfőképp a konvektív aktivitást gyengébben jellemző mennyiségekhez tartozó küszöbértékek meghatározásában lehetnek segítségünkre. Cikkünkben a kutatásunk legfontosabb eredményeit mutatjuk be (1. táblázat).

\section{Módszerek}

Vizsgálatunk alapvetően a hazai meteorológiai radarméréseken, illetve a GFS numerikus modell eredményeinek összevetésén alapul. Elemzésünket a 2011-2013-as évek áprilistól szeptemberig terjedő időszakára végeztük el.

\subsection{A felhasznált radaradatok}

A radarmérések segítségével több, egymástól különböző módon is kaphatunk információt a légkör elemeiröl. Az általános mérési módok közül a PPI (Plan Position Indicator - helyzetet jelző mérés) a legelterjedtebb. PPI-mérés esetén a radar rögzített kibocsátási szög mellett folyamatosan körbefordul, majd ezt az impulzus-kibocsátási szög növelése után ismételten elvégzi, így a légköri elemek elhelyezkedéséről, méretéről és alakjáról összetettebb képet kaphatunk. A PPI-mérés segítségével mindhárom hazai radarral (nyugati országrész: Pogányvár, keleti országrész: Napkor, az ország középső területei: Pestszentlőrinc) szerzett információk alapján, az egyes berendezések által előállított mérésekből létrehozhatók az országos kompozit képek, melyeknek a vizsgálatunkban alkalmazott felbontása időben 15 perc, térben $2 \times 2 \mathrm{~km}$.

\subsection{GFS modelladatok}

Kutatásunk szerves részét képezik a GFS (Global Forecast Sytem) adatai is. A GFS egy globális, hidrosztatikus időjárás-előrejelző modell, mely a National Centers

1. táblázat: A kutatás során vizsgált összes változó. Jelen tanulmányban a vastaggal kiemelt mennyiségekre vonatkozó eredményeinket mutatjuk be.

\begin{tabular}{cc}
\hline Paraméter & Származtatott változók \\
\hline CAPE Index - konvektív hasznosítható potenciális energia & TLR - hömérsékleti gradiens / több szinten \\
MLMUCAPE - kevertrétegü potenciális energia & BII - Boyden Instability Index \\
CIN - konvektív gátlás & TT - Total Totals \\
MLMUCIN - kevertrétegü konvektív gátlás & KI - K-index \\
LI - emelési index & TI - Thompson index \\
BLI - Best Lifted Index & NI - nedvesség index \\
RH - relatív nedvesség / több szinten & SHR - szélnyírás / több magassági szint között \\
Kihullható vízmennyiség & BRN - Bulk-Richardson-szám \\
Specifikus nedvesség 2 m-en & MC - nedvesség konvergencia \\
& $0{ }^{\circ}$ C-os szint magassága \\
\end{tabular}


for Environmental Prediction (NCEP) fejlesztése alatt áll. A modell kezdeti verzióját, az MRF-et (Medium Range Forecast) Sela fejlesztette ki az 1980-as években (Sela, 1982). Ezt követően számos fejlesztésen ment keresztül, napjainkban a horizontális rácsfelbontás már $0,5 \times 0,5$ fok, amely a $\mathrm{mi}$ szélességünkön megközelítőleg $55 \mathrm{~km}$-es rácstávolságot jelent. A vertikális felbontás 64 szintet különböztet meg. Időbeli felbontás alapján két szakasz kü-

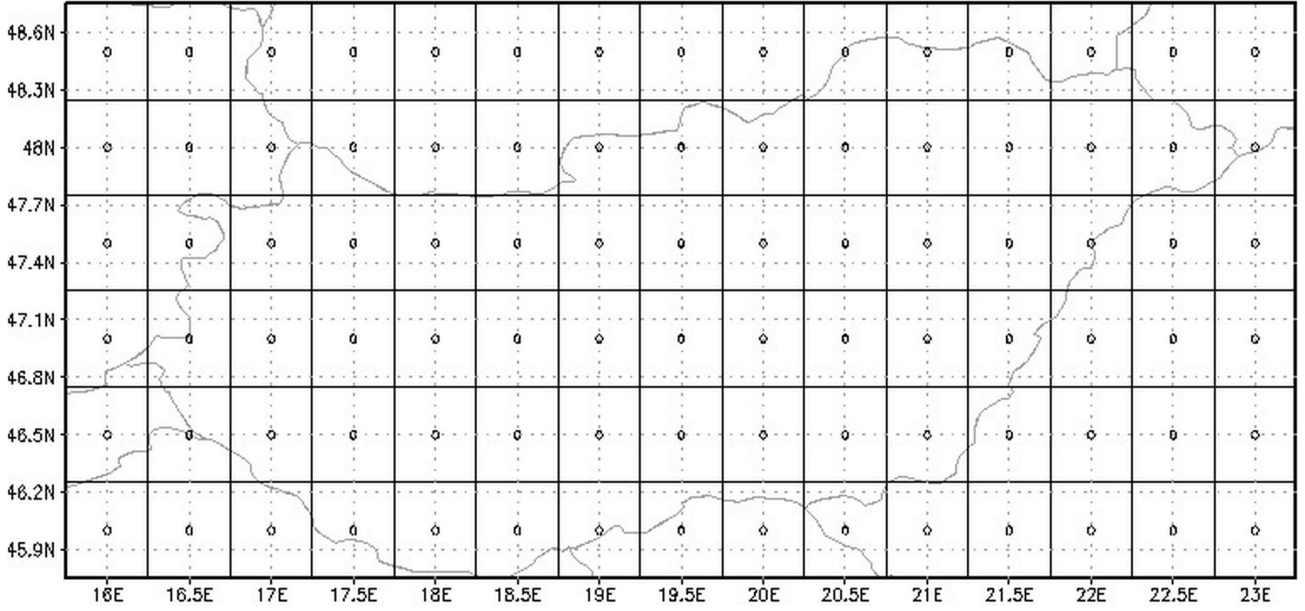

1. ábra: A kutatás során vizsgált rácshálózat. " $0^{\prime \prime}$-val a rácsközéppontokat jelöltük meg. löníthető el: a hat óráként lefutó modell az első részben (0-180 óra) 3 óránként, a másodikban (180-384 óra) 12 óránként szolgáltat információt a légkör várható állapotáról (NCEP, 2013). További előnye, hogy az eredmények szabadon és gyorsan hozzáférhetők. A vizsgálathoz felhasznált GFS-adatok az amerikai NOMADS (National Operational Model Achive \& Distribution System) szerveréről származnak (NOMADS, 2013). Vizsgálatunkhoz a numerikus modell 00, 06, 12 és 18 UTC-s analíziseit, illetve első előrejelzési időlépcsőit (analízis + 3 óra: 03, 09, 15 és 21 UTC) használjuk fel, így kellö, 3 órás finomságú adatsort nyerünk.

\subsection{Zivatarellipszisek elóállítása}

Elsőként egy ismert zivatardetektáló- és követő módszer segítségével Magyarország területére előállítjuk a zivatarellipszisek területi eloszlásait. Ez egy matematikai-programozási eljárás: a TITAN (Thunderstorm Identification, Tracking, Analysis and Nowcasting) (Dixon \& Wiener, 1993). A program az egymást követő radarképeken megjelenő magas reflektivitású gócokat detektálja és követi. Amennyiben talál olyan objektumot, amely meghaladja az általunk elöre meghatározott területi $\left(\mathrm{T}_{\text {limit }}\right)$ és radarjel-erősségi $\left(\mathrm{R}_{\text {limit }}\right)$ küszöbértékeket, területét azonos tulajdonságú ellipszissel közelíti, miközben számolja az egyes rácsdobozokba eső ellipszisközéppontokat is. Az eljárás segítségével megadhatók a zivatarellipszis derékszögü-koordinátarendszerben kifejezett középponti koordinátái, kis- és nagytengelyei, illetve az alkotó képpontok darabszáma is (Horváth et al., 2008). Kutatásunkban a $\mathrm{T}_{\text {limit }}=5$ pixel $\left(20 \mathrm{~km}^{2}\right)$, míg a $\mathrm{R}_{\text {limit }}=45 \mathrm{dBZ}$. Azokat az objektumokat, amelyek eleget tesznek a fenti küszöbértékeknek, heves zivatarellipsziseknek nevezzük.

\subsection{A zivatarellipszisek számának és a GFS modell eredményeinek összevetése}

Az ellipszis-detektáló programrendszer segítségével 15 perces felbontásban elóállítjuk a zivatarellipszisek területi eloszlásait a megadott rácshálózatra (1. ábra). Ekkor minden $55 \times 55 \mathrm{~km}$-es rácsdobozra ismertté válik a zivatarellipszis-középpontok száma a negyedórás időszakokban.

A 15 perces zivatarellipszis számokat a rendelkezésre álló modell kimeneti időpontokra összegezzük az adott modellidőpont plusz-mínusz másfél órás időtartamára. Erre a finomítási időeltolásra azért van szükség, hogy folyamatosan, a modellkimenetekhez illeszkedve láthassuk a detektált zivatarellipszisek keletkezési, áthelyeződési és leépülési folyamatait. Az ellipszisközéppontok számaihoz az 1. táblázatban felsorolt modellváltozókat párosítjuk minden 3 órás időszakra.

A kigyüjtött adatcsoportokat a labilitási energia és a konvektív aktivitás, azaz a detektált zivatarellipszisek száma alapján Énekes (2010) tipizálását követve különböző kategóriákba soroljuk (2. táblázat). Abban az esetben, ha egyetlen ellipszis sem detektálható a vizsgált 3 órás időintervallumban, a leglabilisabb kevertrétegü potenciális energia értéke alapján megkülönböztetünk stabilis, illetve labilis helyzetet.

Utolsó lépésben eredményeinket ún. box-whisker (box plot) vagy dobozdiagramok (Benjamini, 1988)

\section{2. táblázat: A vizsgálat során alkalmazott csoportosítási} rendszer.

\begin{tabular}{|c|c|c|}
\hline $\begin{array}{c}\text { Kategória } \\
\text { neve }\end{array}$ & Kategória leírása & Esetszám \\
\hline $0(\mathrm{~S})$ & $\begin{array}{l}\text { Stabilis helyzet (MLMUCAPE }=0 \\
\mathrm{~J} / \mathrm{kg} \text { ) és nincs jelen zivatarellipszis }\end{array}$ & 230042 \\
\hline $0(\mathrm{~L})$ & $\begin{array}{l}\text { Labilis helyzet (MLMUCAPE }>0 \\
\mathrm{~J} / \mathrm{kg} \text { ) és nincs jelen zivatarellipszis }\end{array}$ & 265260 \\
\hline 1 & $1 \mathrm{db}$ detektált zivatarellipszis & 2846 \\
\hline $2-5$ & $\begin{array}{l}\text { A detektált zivatarellipszisek száma } \\
2 \text { és } 5 \text { között van }\end{array}$ & 3614 \\
\hline $6-10$ & $\begin{array}{l}\text { A detektált zivatarellipszisek száma } \\
6 \text { és } 10 \text { között van }\end{array}$ & 934 \\
\hline$>10$ & $\begin{array}{l}\text { A detektált zivatarellipszisek száma } \\
\text { több mint } 10\end{array}$ & 272 \\
\hline
\end{tabular}


segítségével szemléltetjük. A dobozdiagramokon az adatsorok alábbi statisztikai jellemzőit jelenítjük meg: 95\%os, $75 \%$-os, $25 \%$-os és $5 \%$-os percentilisek. A $25 \%$-os és a 75\%-os percentiliseket alsó és felső kvartiliseknek is nevezzük. Az n százalékos percentilis érték azt jelenti, hogy az adatok n százaléka kisebb, mint a megjelenő érték, azaz ha például a $25 \%$-os percentilis értéke 19 , akkor az adatok 25\%-a kisebb 19-nél. Eredményeink megjelenítésének áttekinthetősége érdekében az ábrákon csak a kvartilisek számértékeit tüntetjük fel, a 95\%-os és 5\%-os percentiliseket a különbségvonalak jelölik.

\section{Eredmények}

Ebben a fejezetben a három évre elvégzett vizsgálat során kapott eredményeinket mutatjuk be. Ezek megjelenítése és elemzése mellett az egyes instabilitási indexek meghatározási módját is ismertetjük.

\subsection{Thompson Index (TI)}

A TI (Haklander \& Van Delden, 2003) a K-index (KI) és a Best Lifted Index (BLI) különbségeként áll elö:

$$
T I=K I-B L I,
$$

ahol

$$
\begin{aligned}
& B L I=T_{\text {körny } 500}-T_{\text {légrész500 }} \\
& K I=\left(T_{850}-T_{500}\right)+T_{D 850}-\left(T_{700}-T_{D 700}\right)
\end{aligned}
$$

A BLI meghatározása általában a termodinamikai diagramok segítségével történik. A talajról indított légrész előbb a száraz adiabata mentén emelkedik, majd a kondenzációs szintet elérve a nedves adiabatán halad tovább egészen az $500 \mathrm{hPa}$-os nyomási szintig, ahol meghatározzuk a légrész hőmérsékleti értékét $\left(T_{\text {legrész } 500}\right)$. Ezt az értéket kivonjuk a környezet $500 \mathrm{hPa}$-os nyomási szintre vonatkozó hőmérsékletéböl $\left(T_{\text {körny500}}\right)$. Ennek a különbségnek a segítségével képet kaphatunk a légoszlopban körülbelül $5 \mathrm{~km}$-es magasságban uralkodó felhajtóerő nagyságáról. Ha a BLI negatív, akkor felhajtóerő áll rendelkezésre. Az egyenletekben $\mathrm{T}_{850}$ a $850 \mathrm{hPa}-\mathrm{os}, \mathrm{T}_{700}$ a $700 \mathrm{hPa}$-os és $\mathrm{T}_{500}$ az $500 \mathrm{hPa}$-os nyomási szinteken mért léghőmérsékleti értékek, míg TD850 a 850 hPa-os és $\mathrm{T}_{\mathrm{D} 700}$ a $700 \mathrm{hPa}$-os nyomási szint harmatpontja. A Kindex egyszerre vizsgálja az $500 \mathrm{hPa}$-os és $850 \mathrm{hPa}$-os nyomási szintek közti hőmérsékleti gradiens értékét és a rendelkezésre álló nedvességet. Minél nagyobb a hömérsékletkülönbség a vizsgált két szint között, annál valószínűbb a zivatarok kialakulásának lehetősége, mert a gradiens növekedésével a levegő rétegzettsége a stabilból instabillá válik. A $850 \mathrm{hPa}$-os nyomási szint harmatpontja a felszínről érkező nedvesség mennyiségét jelzi, mely minél nagyobb, annál több energiával rendelkezik az objektum. Ha a fenti feltételek kedvezőek, de a köztes $700 \mathrm{hPa}$-os szinten nincs elegendő nedvesség (vagyis a hőmérséklet és a harmatpont különbsége nagy), akkor nem alakul ki heves konvektív jelenség. Mivel a BLI értéke konvekciót támogató környezetben negatív, ezért a TI meghatározásakor a K-indexből kivonva kapunk egyre nagyobb TI értéket, ahogyan a zivatarok kialakulásának esélye növekszik.

A 2. ábra alapján elmondható, hogy $30^{\circ} \mathrm{C}$-ot meghaladó értékek esetén már gyakran kialakulnak $45 \mathrm{dBZ}-\mathrm{t}$ meghaladó zivatarellipszisek, míg a detektálható objektumok nélküli labilitás már $20^{\circ} \mathrm{C}$ fölötti értékek esetén is jelentkezik. A zivatarellipsziseket tartalmazó kategóriák értékei viszonylag szük tartományon belül helyezkednek el, a $33^{\circ} \mathrm{C}$-os küszöbérték meghaladása már nagy valószínüséggel eredményez több ellipszist. Az index szélsőértékeinek vizsgálatai során levonható a következtetés, hogy minél több ellipszis figyelhetô meg, annál magasabb, de mindenképpen pozitív minimumértékek fordulnak elö, míg a maximumok elérik a $48-52^{\circ} \mathrm{C}$-ot (3. táblázat).

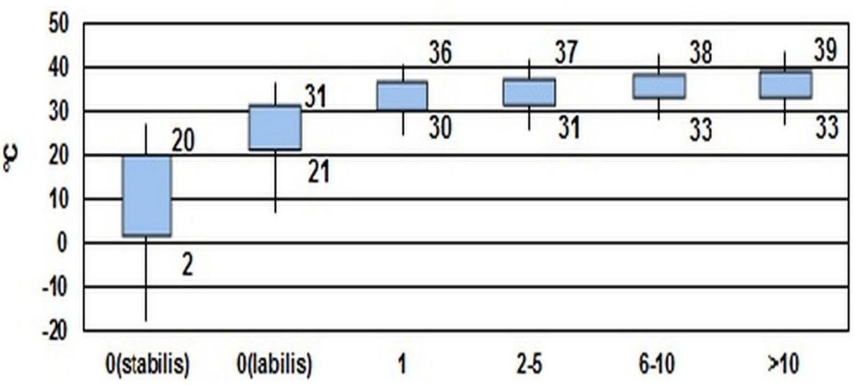

2. ábra: A Thompson Index dobozdiagramja.

3. táblázat: A Thompson Index előfordult szélsőértékei az egyes kategóriákban.

\begin{tabular}{ccccccc}
\hline $\mathbf{4 5} \mathbf{d B Z}$ & $\mathbf{0}(\mathbf{S})$ & $\mathbf{0}(\mathbf{L})$ & $\mathbf{1}$ & $\mathbf{2 - 5}$ & $\mathbf{6}-\mathbf{1 0}$ & $>\mathbf{1 0}$ \\
\hline Minimum & -72 & -52 & -26 & 3 & 16 & 17 \\
Maximum & 37 & 52 & 49 & 49 & 51 & 48 \\
\hline
\end{tabular}

A vizsgálat során kapott eredményeink nem térnek el jelentősen az index nemzetközi szakirodalomban meghatározott $28,5^{\circ} \mathrm{C}$-os küszöbértékétől (Brothers, 2008).

\subsection{Hozzáférhetố konvektív potenciális ener- gia (CAPE)}

A CAPE az az energiamennyiség, ami a felszínről induló légrészben emelkedés közben maximálisan felszabadulhat, azaz a termodinamikai diagramon a pozitív terület nagysága a szabad konvekció szintje és a kiegyenlítési szint között. A szabad konvekció szintje az a magasság, ahol a felfelé mozgó légrész hőmérséklete megegyezik a környezet hőmérsékletével, illetve e felett már melegebb annál, biztosítva ezzel a további emelkedést. A kiegyenlítési szint pedig az a szint, ahol a légrész hőmérséklete már ismét megegyezik a környezetével, így a cella már nem kap többletenergiát a további emelkedéshez. A hozzáfér- 
hető konvektív potenciális energiát gyakran $S B C A P E$-vel is jelölik, ami az angol „surface based” (talajalapú) kifejezésből ered. Egyéb származtatott változatai még a $M U$ $C A P E$ (legnagyobb hozzáférhető potenciális energia) és az $M L C A P E$ (kevertrétegü potenciális energia) vagy ezek kombinációja, az MLMUCAPE (Markowski \& Richardson, 2010). A tapasztalat azt mutatja, hogy célszerübb a kevert típusú CAPE alkalmazása, hiszen esetében már nem csak a felszíni adatokat vesszük figyelembe, hanem a légréteg 1600-1800 méteres magasságig terjedő hőmérsékleti és nedvességi viszonyait is. Az MLMUCAPE még előnyösebb, mivel ekkor az alsó légrétegek különböző tartományaiból kevert és indított CAPE értékek közül a leglabilisabbat vesszük. A kevert típusú labilitási energiák, ellentétben a talajalapúval, megjelenítik az emelt (például éjszakai) konvekciót is, emiatt az elkülönítési osztályozásnál is az MLMUCAPE-t használjuk.

Ahogy 3. ábrán is látható, az MLMUCAPE esetében a „nullás” és „nem nullás” esetek viszonylag jól elkülönülnek. A egyetlen detektált ellipszis esetében körülbelül 100-200 J/kg fölötti, míg több ellipszis kialakulásához minimum 200-300 J/kg-nyi energia szükséges. Érdekesség, hogy a legnagyobb CAPE érték éppen egy labilis, de zivatarellipszist nem detektáló esetben jelent meg, a zivatarellipszises helyzetekben jellemzően annál alacsonyabb, 2400-2800 J/kg közötti csúcsértékek vannak, amely az ellipszisszám növekedésével fordított arányban áll (4. táblázat). Ennek lehetséges oka, hogy gyengébb labilitás esetén a külső tényezők szerepe erőteljesebben megmutatkozhat, így a légrész emelését biztosító energiamennyiség származhat a szélnyírás és/vagy orográfia, illetve frontvonal együttes hatásából. A legmagasabb érték megjelenésekor valószínüleg még csak kevésbé heves cellák alakultak ki vagy nem állt rendelkezésre elegendő középszinti nedvesség.

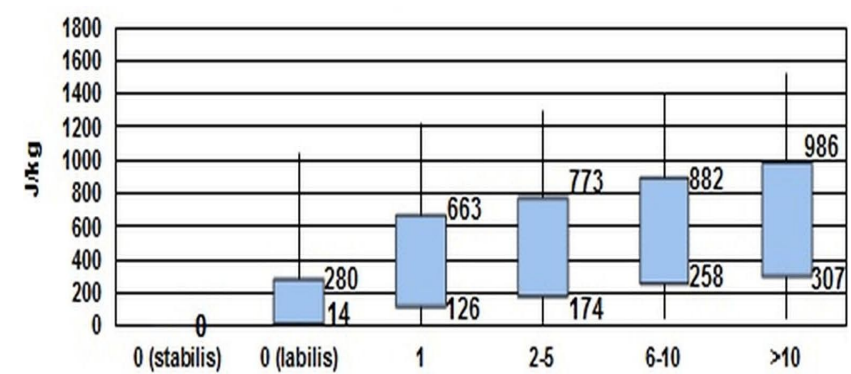

3. ábra: A kevertrétegú, leglabilisabb CAPE (MLMUCAPE) dobozdiagramja.

4. táblázat: Az MLMUCAPE előfordult szélsőértékei az egyes kategóriákban.

\begin{tabular}{ccccccc}
\hline $\mathbf{4 5} \mathbf{d B Z}$ & $\mathbf{0 ( S )}$ & $\mathbf{0 ( L )}$ & $\mathbf{1}$ & $\mathbf{2 - 5}$ & $\mathbf{6 - 1 0}$ & $>\mathbf{1 0}$ \\
\hline Minimum & 0 & 1 & 0 & 0 & 61 & 49 \\
Maximum & 0 & 4738 & 2868 & 2710 & 2611 & 2401 \\
\hline
\end{tabular}

\subsection{Kihullható vízmennyiség}

A kihullható vízmennyiség egy olyan nedvességi paraméter, amely egy adott légoszlop teljes vízgőztartalmának kihullását adja meg (Solot, 1939). A $\mathrm{z}_{1}>\mathrm{z}_{0}$ magassági szintek közötti rétegben a kihullható víztartalmat az alábbi összefüggés alapján kaphatjuk meg:

$$
p=\int_{z 0}^{z 1}\left(\rho_{\mathrm{v}}+\rho_{\mathrm{w}}+\rho_{\mathrm{i}}\right) \mathrm{dz}
$$

ahol $\rho_{v}, \rho_{w}$ és $\rho_{i}$ az egyes vízfázisokra (v: vízgőz; w: folyékony víz; i: jég) vonatkozó sűrüségi értékek. Ez egy elméleti érték, amely természetesen függ a hőmérséklettől is, hiszen minél melegebb a levegő, annál több vízgőzt képes befogadni, amivel nő a légréteg kihullási potenciálja is. Ha a kihullható vízmennyiség várható értéke meghaladja a $25 \mathrm{~mm}$-t, akkor felhőszakadásra lehet számítani, amely lassan áthelyeződő zivatarok esetében kiemelt jelentőséggel bír, hiszen villámárvizeket okozhat.

A kihullható vízmennyiség vizsgálata során is viszonylag jól elkülönültek a stabilis és labilis, illetve a „nullás” és a „nem nullás” esetek (4. ábra). Elmondhatjuk, hogy amennyiben a légréteg kihullható vízmennyisége kisebb, mint $20 \mathrm{~mm}$, akkor kis eséllyel kell számítanunk konvektív esemény kialakulására a légkörben. Azonban, ha értéke meghaladja a 26 mm-t, akkor nagy valószínüséggel jön létre heves konvekció. Látható még, hogy a kihullható vízmennyiség elméleti értéke az ellipszisszám növekedésével emelkedik, hiszen minél több zivatarellipszis keletkezéséhez adottak a légköri feltételek, annál nagyobb mértékủ csapadékhullásra számíthatunk. Az 5 . táblázatban megjelenített szélsőértékekből kiderül, hogy már egyetlen detektált zivatarellipszis létrejöttéhez is legalább 8 mm-nyi kihullható vízmennyiség társult (amely a magasabb kategóriák felé haladva méginkább nőtt), míg a maximumok a $46 \mathrm{~mm}$-t is elérték.

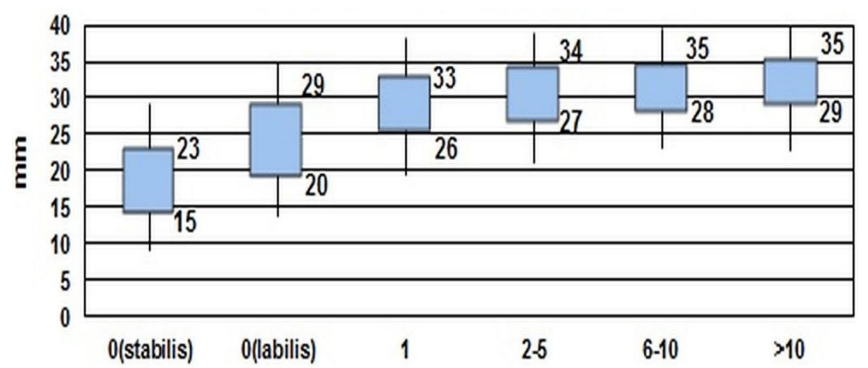

4. ábra: A kihullható vízmennyiség dobozdiagramja.

5. táblázat: A kihullható vízmennyiség előfordult szélsőértékei az egyes kategóriákban.

\begin{tabular}{ccccccc}
\hline $\mathbf{4 5} \mathbf{d B Z}$ & $\mathbf{0 ( S )}$ & $\mathbf{0 ( L )}$ & $\mathbf{1}$ & $\mathbf{2 - 5}$ & $\mathbf{6 - 1 0}$ & $>\mathbf{1 0}$ \\
\hline Minimum & 2 & 4 & 8 & 14 & 16 & 19 \\
Maximum & 43 & 47 & 45 & 46 & 46 & 46 \\
\hline
\end{tabular}


Mivel a csapadékeloszlást nagy térbeli változékonyság jellemzi, így a kihullható vízmennyiség meghatározása is inkább regionálisan értelmezhető. Összevetve azonban eredményeinket a nemzetközi szakirodalommal, például Duplika \& Reuter (2005) kanadai vizsgálatai alapján is megadható egy $25 \mathrm{~mm}$-es átlagos küszöbérték a hevesebb konvektív események kialakulásához.

\subsection{Specifikus nedvesség}

A specifikus nedvesség a nedves levegőben lévő vízgőz és a nedves levegő tömegarányát adja meg (Götz \& Rákóczi, 1981).

A specifikus nedvességre kapott eredményeink alapján elkészített eloszlási diagramon elkülöníthetők egymástól a stabilis, illetve labilis, azon belül is az ellipsziseket tartalmazó, heves konvekcióval járó kategóriák (5. ábra). Jól látszik, hogy körülbelül $9 \mathrm{~g} / \mathrm{kg}$-nál kisebb értékek esetén viszonylag kis valószínűséggel fordulnak elő zivatarellipszisek a vizsgált 3 órás időintervallumokban. Ez az érték az ellipszisszám növekedésével együtt haladva folyamatos emelkedést mutat, azaz több zivatarellipszis esetén nagyobb mennyiségü vízgőz található az egységnyi tömegü nedves levegőben, 2 méteres magasságban. A köztük fennálló kapcsolatra lehetséges magyarázat, hogy az emelkedő légrész hủlése során a kondenzálódó vízgőzbőll további energia szabadul fel (látens hő), amely a légtest melegítésére fordítódik, így az még több nedvességet lesz képes magában tartani. A szélsőértékek is hasonló eredményt tükröznek, sőt a 6. táblázatból az is kiderül, hogy az intenzívebb konvekciót tartalmazó kategóriákban egyre szükebb tartományra korlátozódnak a minimum-, illetve maximumértékek.

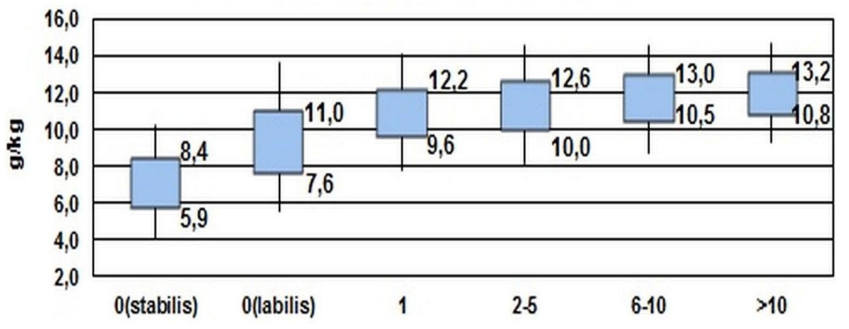

5. ábra: A specifikus nedvesség dobozdiagramja.

6. táblázat: A 2 m-es magasságban számított specifikus nedvesség elófordult szélsőértékei az egyes kategóriákban.

\begin{tabular}{ccccccc}
\hline $\mathbf{4 5} \mathbf{d B Z}$ & $\mathbf{0 ( S )}$ & $\mathbf{0 ( L )}$ & $\mathbf{1}$ & $\mathbf{2 - 5}$ & $\mathbf{6}-\mathbf{1 0}$ & $>\mathbf{1 0}$ \\
\hline Minimum & 1,2 & 1,8 & 4 & 5,5 & 6 & 7,4 \\
Maximum & 15,2 & 23,1 & 18,9 & 18,2 & 19,1 & 18 \\
\hline
\end{tabular}

\subsection{Nedvességi Index (NI)}

A NI a $850 \mathrm{hPa}$-os, a $700 \mathrm{hPa}$-os és az $500 \mathrm{hPa}$-os magassági szintek hőmérsékleti és harmatponti adataiból számolt harmatpont-depressziót veszi figyelembe (Litynska, Parfiniewicz, \& Pinkowski, 1976):

$$
N I=\left(T-T_{D}\right)_{850}+\left(T-T_{D}\right)_{700}+\left(T-T_{D}\right)_{500},
$$

ahol $\left(\mathrm{T}-\mathrm{T}_{\mathrm{D}}\right)_{850}$ a $850 \mathrm{hPa}$-os szinthez tartozó, $\left(\mathrm{T}-\mathrm{T}_{\mathrm{D}}\right)_{700}$ a $700 \mathrm{hPa}$-os szinten számolt, a $\left(\mathrm{T}-\mathrm{T}_{\mathrm{D}}\right)_{500}$ az $500 \mathrm{hPa}$ os szinti hőmérséklet és harmatpont különbségek. Ennek alapján az index értéke és a légoszlop nedvességtartalma fordított arányosságban állnak egymással.

A NI eloszlási diagramján látható, hogy a vizsgált stabilis és labilis kategóriák értékei nem határolódnak el élesen egymástól. Általánosan elmondható, hogy a zivatarellipszis-szám növekedésével az egyes kategóriákhoz tartozó felső kvartilisek értékei csökkennek, de a heves konvektív jelenségeket detektáló esetekben mind az alsó, mind pedig a felső kvartilisek értékei közel együtt mozognak. A 6. ábrán jól látszik, hogy heves konvekció az esetek döntő többségében $22^{\circ} \mathrm{C}$-os érték alatt fordult elö, de önmagában ez kevés információ egy intenzív zivatar kialakulási valószínűségének eldöntéséhez, hiszen ilyen értékek a stabilis, illetve labilis, de ellipszist nem tartalmazó esetekben is viszonylag gyakran megjelentek. A 7. táblázat mutatja, hogy a kategóriákhoz tartozó maximumértékek fordított arányosságban állnak az ellipszisszám növekedésével, hiszen minél nedvesebb a vizsgált légréteg, annál alacsonyabbak lesznek a különböző nyomási szintekhez tartozó harmatpont-deficit értékek.

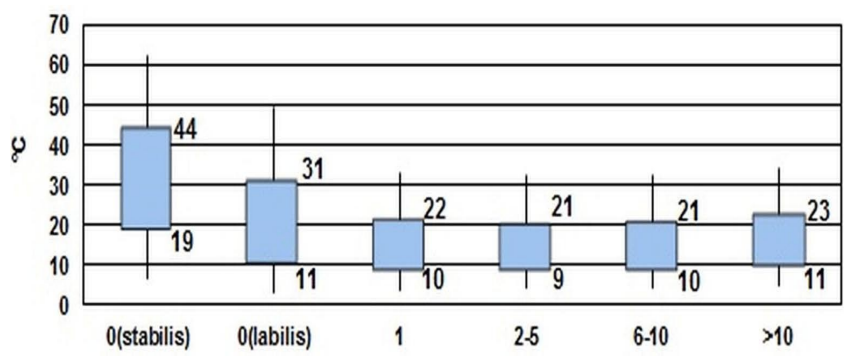

6. ábra: A Nedvességi Index eloszlási diagramja.

7. táblázat: A 2 m-es magasságban számított specifikus nedvesség előfordult szélsőértékei az egyes kategóriákban.

\begin{tabular}{ccccccc}
\hline $\mathbf{4 5} \mathbf{d B Z}$ & $\mathbf{0 ( S )}$ & $\mathbf{0 ( L )}$ & $\mathbf{1}$ & $\mathbf{2 - 5}$ & $\mathbf{6 - 1 0}$ & $>\mathbf{1 0}$ \\
\hline Minimum & 0 & 0 & 0 & 0 & 1 & 0 \\
Maximum & 120 & 95 & 58 & 61 & 61 & 49 \\
\hline
\end{tabular}

\subsection{Különböző nyomási szintek közötti verti- kális hőmérsékleti gradiens (TLR)}

A TLR a környezet hőmérsékletének magassággal történő változását mutatja meg. Ha a TLR értéke körülbelül $1{ }^{\circ} \mathrm{C}$ ot változik 100 méterenként, akkor száraz adiabatikus rétegződésről beszélünk. Amennyiben a TLR körülbelül $5^{\circ} \mathrm{C} / \mathrm{km}$, nedves adiabatikusnak tekintjük a légrétegzödést. Ha a környezet hőmérsékleti gradiense nagyobb, mint az emelkedő légrészecskéé, akkor a rétegződés instabil, ugyanis ekkor a cella kevésbé hül, így melegebb marad, mint a környezete, ez pedig az emelkedés feltétele. Fordított esetben, azaz ha a környezet hőmérsékleti 
gradiense az alacsonyabb, a légkört stabilan rétegzettnek tekintjük. A hőmérsékleti gradiens különböző nyomási szintek között is vizsgálható, pontosabb képet kapva ezzel a troposzféra egyes részeiröl.

A $850 \mathrm{hPa}$-os és az $500 \mathrm{hPa}$-os nyomási szintek közötti vertikális hőmérsékleti gradiens eloszlási diagramján csak kismértékủ elkülönülés fedezhető fel a vizsgált kategóriák között. A TLR a zivatarellipszist tartalmazó kategóriákban $6-7^{\circ} \mathrm{C} / \mathrm{km}$ körül helyezkedik el, míg a „,nullás" típusoknál alacsonyabb értékek is megjelennek ( 7 . ábra). A végzett szélsőérték vizsgálatokból az is kiderül, hogy a minimum-, illetve a maximumértékek együttesen egy szük tartományban változnak mind a stabilis, mind a labilis esetekben, ezért az index használata során mindenképp figyelembe kell vennünk egyéb labilitási indexek számértékeit is a megfelelő pontosságú előrejelzés elkészítéséhez (8. táblázat).

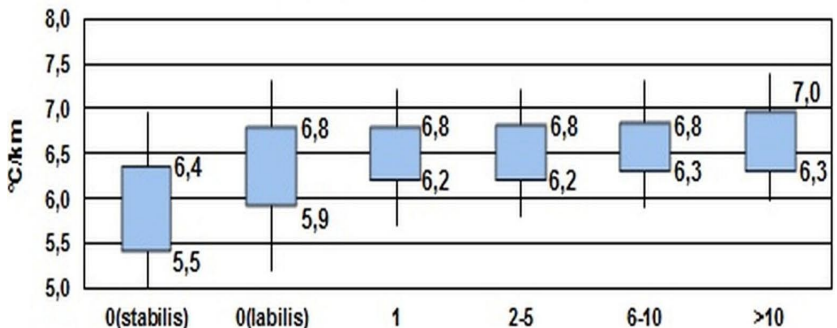

7. ábra: A 850 és az 500 hPa-os nyomási szintek közötti vertikális hômérsékleti gradiens dobozdiagramja.

8. táblázat: A 850 és az 500 hPa-os szintek közötti vertikális hômérsékleti gradiens előfordult szélsőértékei az egyes kategóriákban.

\begin{tabular}{ccccccc}
\hline $\mathbf{4 5} \mathbf{d B Z}$ & $\mathbf{0}(\mathbf{S})$ & $\mathbf{0}(\mathbf{L})$ & $\mathbf{1}$ & $\mathbf{2 - 5}$ & $\mathbf{6 - 1 0}$ & $>\mathbf{1 0}$ \\
\hline Minimum & 3,1 & 2,9 & 4,7 & 4,1 & 4,7 & 5,2 \\
Maximum & 8,4 & 8,8 & 8,3 & 8,1 & 7,7 & 8 \\
\hline
\end{tabular}

A kutatás során megvizsgáltuk még az 1000 és 850 hPa-os, a 700 és $500 \mathrm{hPa}$-os, illetve a 700 és $400 \mathrm{hPa}$-os nyomási szintekhez tartozó hőmérsékleti gradienseket is, de esetükben még gyengébb szétválaszthatóság jelenik meg a definiált kategóriák között, ezért csak a fent említett típus eredményeit közöljük.

\subsection{Különböző magassági szintek közötti verti- kális szélnyírás}

A szélnyírások a szélvektorok térbeli változásait szemléltetik. Az előrejelzési gyakorlatban általában két szintet hasonlítanak össze, leggyakrabban a $0-1 \mathrm{~km}$ (körülbelül 1000 és $900 \mathrm{hPa}$ ), a $0-2,5 \mathrm{~km}$ (körülbelül 1000 és 750 $\mathrm{hPa})$, a $0-6 \mathrm{~km}$ (1000 és $450 \mathrm{hPa})$, illetve a $0-8 \mathrm{~km}(1000$ és $350 \mathrm{hPa})$ szintek közötti szélnyírás kap figyelmet. Vizsgálatunkban a sebesség szerinti különbségeket elemezzük, de az elörejelzési térképeken szokás a szélnyírás vektorának irányát is megjeleníteni.

A 8. ábrán bemutatott, 0 és $6 \mathrm{~km}$-es magassági szintek közötti szélnyírás dobozdiagramján gyakorlatilag nincs érzékelhető elhatárolódás a stabilis, illetve a labilis kategóriák között. Elmondható, hogy az értékek széles skálán mozognak, így szükebb tartományt nem tudunk megadni. Azonban fontos kiemelni, hogy a legnagyobb értékek általában az ellipszis nélküli esetekben fordulnak elö, tehát nagy szélnyírásnál csak ritkán alakul ki heves konvekció (9. táblázat).

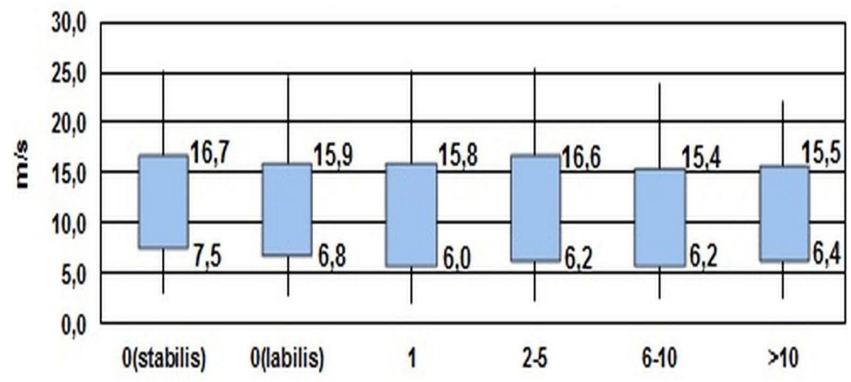

8. ábra: Az 1000 és 450 hPa (0-6 km-es) szintek közötti szélnyírás dobozdiagramja.

9. táblázat: Az 1000 és 450 hPa (0-6 km-es) szintek közötti szélnyírás előfordult szélsőértékei az egyes kategóriákban.

\begin{tabular}{ccccccc}
\hline $\mathbf{4 5} \mathbf{d B Z}$ & $\mathbf{0 ( S )}$ & $\mathbf{0}(\mathbf{L})$ & $\mathbf{1}$ & $\mathbf{2 - 5}$ & $\mathbf{6}-\mathbf{1 0}$ & $>\mathbf{1 0}$ \\
\hline Minimum & 0 & 0 & 0,3 & 0,1 & 0,3 & 0,4 \\
Maximum & 54,1 & 52,8 & 37,6 & 37,3 & 37,3 & 28,4 \\
\hline
\end{tabular}

Az eredményeket a tapasztalat is megerősíti, a túl erős szélnyírás többnyire rontja a heves konvekció esélyeit, kivéve, ha az rendkívül erős labilitással párosul, ez pedig Magyarország területén viszonylag ritkán fordul elő.

\subsection{A vizsgált változók összegzése}

Ahogy a tanulmányban bemutatott labilitási mérőszámok és egyéb mennyiségek dobozdiagramjain is látszik, nem minden vizsgált változóról mondható el, hogy segítségével megfelelő pontossággal jellemezhető a konvektív környezet, hiszen egyes indexeknél még a stabilis és labilis légköri állapotok sem különíthetők el élesen egymástól.

Néhány vizsgált instabilitási, szélnyírási, illetve nedvességi változót tekintve azonban megadhatunk olyan küszöbértékeket, amelyek megjelenése esetén a gyakorlatban kis eséllyel számíthatunk konvekcióra. A 10. táblázatban összefoglalt adatok alapján látszik, ha az elörejelzendő időszakra a BLI értéke magasabb, mint $2^{\circ} \mathrm{C}$, konvektív esemény csak kis valószínüséggel fordulhat elö az adott területen. Ugyanez mondható el akkor is, ha a KI és/vagy a TI értéke alacsonyabb 24 , illetve $25^{\circ} \mathrm{C}$ nál. Ha a modelladatok alapján a kihullható vízmennyiség nem haladja meg a $20 \mathrm{~mm}$-t, valamint a 2 méteres magasságban várható specifikus nedvesség értéke a $8 \mathrm{~g} /$ kg-ot, akkor a légköri feltételek szintén nem kedveznek a 
konvekciónak. A heves időjárási események kialakulásának eldöntésében segítségünkre lehet még a NI, valamint a tanulmányban nem részletezett, de megvizsgált Total Totals Index (Miller, 1967) és Boyden Instability Index (Boyden, 1963) értékeinek áttekintése is.

10. táblázat: A vizsgált mennyiségekhez tartozó (heves) konvekciómentes küszöbértékek.

\begin{tabular}{cc}
\hline Változó & $\begin{array}{c}\text { Nem valószínü heves } \\
\text { konvekció }\end{array}$ \\
\hline $\mathrm{LI}\left[{ }^{\circ} \mathrm{C}\right]$ & $>4$ \\
$\mathrm{BLI}\left[{ }^{\circ} \mathrm{C}\right]$ & $>2$ \\
$\mathrm{KI}\left[{ }^{\circ} \mathrm{C}\right]$ & $<24$ \\
$\mathrm{TI}\left[{ }^{\circ} \mathrm{C}\right]$ & $<25$ \\
Kihullható vízmennyiség & $<20$ \\
{$[\mathrm{~mm}]$} & $<8$ \\
Specifikus nedvesség & $<95$ \\
{$[\mathrm{~g} / \mathrm{kg}]$} & $<45$ \\
$\mathrm{BII}\left[{ }^{\circ} \mathrm{C}\right]$ & $>32$ \\
$\mathrm{TT}\left[{ }^{\circ} \mathrm{C}\right]$ & \\
$\mathrm{NI}\left[{ }^{\circ} \mathrm{C}\right]$ &
\end{tabular}

A fenti táblázatban összegyüjtött küszöbértékeket az egyes indexekre vonatkozó 5\%-os, vagy 95\%-os percentilisek értékeinek vizsgálatával határoztuk meg attól függően, hogy az adott labilitási mérőszám magas vagy alacsony értéke jellemzi a konvektív folyamatokat. Az említett kilenc változó közül hat esetében megadhatók szükebb tartományok is a légköri heves konvekció jellemzésére.

A 11. táblázatban megjelenített, a különböző változókra vonatkozó intervallumokat a vizsgált, egymástól jól elkülönülö kategóriák 25 , illetve $75 \%$-os percentilisek előforduló értékeinek segítségével határoztuk meg. A táblázat második oszlopában azokat az értékeket jelenítettük meg, amelynek elérése esetén nagy valószínüséggel számíthatunk kialakuló heves légköri eseményre. A harmadik oszlop azokat a küszöbértékeket tartalmazza, amely az adott mennyiségre vonatkozóan biztosítja az előrejelzőt arról, hogy várható több, akár nagyobb területet is lefedő heves zivatar. Például a KI esetében elmondható, ha értéke meghaladja a $29^{\circ} \mathrm{C}$-ot, a légköri feltételek kedvezőek intenzív konvektív jelenség kialakulásához, míg a $31^{\circ} \mathrm{C}$-nál magasabb érték nagyobb számú detektálható objektum megjelenését is jelezheti.

A táblázat segítségével összegzett eredmények így már könnyedén és azonnal alkalmazhatók az előrejelzések készítésénél, javítva azok pontosságát.

\section{5. Összegzés}

A heves konvekciót vizsgáló kutatásunk célja, hogy kiderítsük, mely labilitási mérőszámok alkalmazása javíthatja leginkább a zivataros helyzetben készülő előrejelzések pontosságát. A vizsgált változók a GFS időjárás-előrejelző modell amerikai szerveréröl származnak. Az elemzéshez felhasználtuk még az Országos Meteorológiai Szolgálat radarhálózatában található berendezések méréseit is. A keletkező zivatarok radarképeken megjelenő, szabálytalan alakú alakzatait ugyanakkora területü ellipszisekkel modelleztük. A kutatás során csak azokat az objektumokat vettük figyelembe, amelyek eleget tettek az általunk előre meghatározott területi és radarjel-erősségi küszöbértékeknek, tehát legalább $20 \mathrm{~km}^{2}$-nyi területen minimum $45 \mathrm{dBZ}$-s reflektivitással rendelkeztek. A kigyüjtött adatcsoportok osztályozására hattagú rendszert alkalmaztunk, amelyben az egyes, vizsgált kategóriákat a detektálható zivatarellipszisek száma alapján különítettük el egymástól. Utolsó lépésként eredményeinket dobozdiagramok segítségével jelenítettük meg. Megvizsgáltuk emellett a modellben megtalálható, illetve az általunk származtatott változók előforduló szélsőértékeit is a 2011-2013 közti időszakra, Magyarország területére.

A vizsgálat során összesen 52 labilitási indexet és egyéb paramétert elemeztünk, jelenleg ezek közül hetet mutattunk be. Közülük a Thompson Indexet, az MLMUCAPEet és a kihullható vízmennyiséget találtuk kifejezetten

11. táblázat: Az egyes indexek esetén a heves konvekció kialakulásának kedvező tartományok.

\begin{tabular}{ccc}
\hline Változó & Kialakulhat heves zivatar & Nagyobb számban is kialakulhatnak heves zivatarok \\
\hline $\mathrm{LI}\left[{ }^{\circ} \mathrm{C}\right]$ & $\leq 0$ & $\leq-1$ \\
$\mathrm{BLI}\left[{ }^{\circ} \mathrm{C}\right]$ & $\leq-0,5$ & $\leq-1,5$ \\
$\mathrm{KI}\left[{ }^{\circ} \mathrm{C}\right]$ & $\geq 29$ & $\geq 31$ \\
$\mathrm{TI}\left[{ }^{\circ} \mathrm{C}\right]$ & $\geq 30$ & $\geq 33$ \\
Kihullható vízmenny. $[\mathrm{mm}]$ & $\geq 26$ & $\geq 29$ \\
Specifikus nedvesség $[\mathrm{g} / \mathrm{kg}]$ & $\geq 9$ & $\geq 11$ \\
\hline
\end{tabular}


megbízhatónak a heves konvekcióval járó légköri események elörejelzéséhez. Találtunk azonban olyan változókat is, amelyeknél a zivatarellipszis-szám növekedése és az index értéke között nem volt olyan erös összefüggés, a tanulmányban erre példa a szélnyírás, a Nedvességi Index és a különböző magassági szintek közötti vertikális hőmérsékleti gradiensek. A megfelelő pontosságú előrejelzés készítéséhez nem szabad azonban figyelmen kívül hagynunk e mennyiségek értékeit sem, hiszen gyakran hordoznak fontos információt a konvektív környezet állapotáról. Az egyes mérőszámok alkalmazásánál mindenképp szükséges több paraméter együttes szemlélete, valamint nagy segítséget jelenthet az is, ha ismerjük, melyek a hozzájuk tartozó előfordult minimum-, illetve maximumértékek ahhoz, hogy a lehető legpontosabb elörejelzést készíthessük.

Jövőbeli terveink között szerepel a vizsgálati idő további hosszabbítása, valamint szeretnénk jelenlegi eredményeinket magasabb reflektivitási küszöbértékek eredményeivel is összehasonlítani, átfogóbb képet adva ezzel az intenzív légköri események szinoptikus és lokális feltételeiről. Fontosnak tartjuk esettanulmányok készítését, azt vizsgálva segítségükkel, hogy a paraméterek mely kombinációja a legkedvezőbb a heves zivatarok kialakulásához. Ezeken túlmenően célszerű lenne még a felhasznált radarméréseket más elörejelző modellekben található adatokkal is összevetni a megfelelő időszakokra, összehasonlítva ezzel a modellek érzékenységét a konvektív folyamatokra. A bemutatott eredmények azonnal alkalmazhatóak a mindennapi elörejelzések, a veszélyjelzések készítésénél, emellett hasznosak lehetnek a balatoni viharjelzésnél, illetve fontos információkat nyújthatnak a repülésmeteorológia számára is.

\section{Irodalomjegyzék}

Benjamini, Y. (1988). Opening the Box of a Boxplot. The American Statistician, 42, 257-262. doi: $10.2307 / 2685133$

Boyden, C. J. (1963). A simple instability index for use as a synoptic parameter. Meteorological Magazine, 92, 198-210.

Brothers, D. A. (2008, October). Forecasting summertime convection in western North Dakota using RAOB. Paper presented at the $24^{\text {th }}$ Conference on Severe Local Storms, Savannah, GA, Bismarck, ND: North Dakota Atmospheric Resource Board

Dixon, M., \& Wiener, G. (1993). TITAN - Thunderstorm Identification, Tracking, Analysis, and Nowcasting - A Radar-based Methodology. Journal of Atmospheric and Oceanic Technology, 10, 785-797. doi: 10.1175/15200426(1993)010\%3C0785:ttitaa\%3E2.0.co:2

Dupilka, M. L., \& Reuter, G. W. (2006). Forecasting Tornadic Thunderstorm Potential in Alberta Using Environmental Sounding Data. Part II: Helicity, Precipitable Water, and Storm Convergence. Weather and Forecasting, 21, 336-346. doi:10.1175/waf922.1

Énekes, N. A. (2010). Intenzív konvektív folyamatok környezetének vizsgálata modell analizisek alapján (Diplomamunka kézirat). ELTE TTK Meteorológiai Tanszék, Budapest

Götz, G., és Rákóczi, F. (1981). A dinamikus meteorológia alapjai (pp. 177-199). Budapest: Tankönyvkiadó.

Haklander, A. J., \& Van Delden, A. (2003). Thunderstorm predictors and their forecast skill for the Netherlands. Atmospheric Research, 67-68, 273-299. doi:10.1016/ s0169-8095(03)00056-5

Hegyfoky, K. (1912). A zivatarok napi periódusa Magyarország sík és hegyes vidékén. Időjárás, 16, 269-272.

Horváth, Á., Ács, F., \& Seres, A. T. (2008). Thunderstorm climatology analyses in Hungary using radar observations. Időjárás, 112, 1-13.

Kohlmann, M. (2013). Konvektiv paraméterek vizsgálata modellanalízisek alapján (Diplomamunka kézirat). ELTE TTK Meteorológiai Tanszék, Budapest

Litynska, Z., Parfiniewicz, J., \& Pinkowski, H. (1976). The prediction of air mass thunderstorms and hails. $W M O$ Bulletin, 450, 128-130.

Markowski, P., \& Richardson, Y. (2010). Mesoscale Meteorology in Midlatitudes. Wiley-Blackwell: Chichester doi:10.1002/9780470682104

Miller, R. C. (1967). Notes on analysis and severe storm forecasting procedures of the Military Weather Warning 


\section{TFK}

Center. Volume 200 of Technical Report, Washington, DC: Air Weather Service, United States Air Force

NCEP (2013). National Centers for Environmental Prediction (NCEP) EMC Model Documentation. http:// www.emc.ncep.noaa.gov/modelinfo/index.html [olvasva: 2013. október 1-jén]

NOMADS (2013). Data Access, Hi-Res NCEP Model Datasets, GFS [http://nomads.ncdc.noaa.gov/data/gfs4/]. Az adatok elérhetők: http://nomads.ncdc.noaa.gov/data/ gfs4/ [elérés: 2013. augusztus 01-15.]

Riegl, S. (1902). A zivatarok évi és napi periódusa Kalocsán 1901-ben, a Schreiber-féle viharjelző nyomán. Idöjárás, 6, 196-201.

Sela, J. G. (1982). The NMC Spectral Model. NOAA Technical Report National Weather Service Series 30, Rockville: U.S. Department of Commerce
Seres, A. T. (2006). Heves konvektiv folyamatok objektív vizsgálat (Diplomamunka kézirat). ELTE TTK Meteorológiai Tanszék, Budapest

Solot, S. B. (1939). Computation of Depth of Precipitable Water in a Column of Air. Monthly Weather Review, 67, 100-103. doi: 10.1175/1520-0493(1939)67\%3C100: codopw\%3E2.0.co;2

Szalay-Ujfalussy, L. (1917). A zivatarok és a légnyomás. Idöjárás, 21, 158-159.

Szudár, B. (1992). A zivatartevékenység és néhány konvektív jelenség klimatológiai-statisztikai vizsgálata. Légkör, 37, 2-7.

Váradi, A. (1898). A zivatarképződésről. Időjárás, 2, 182-186. 